\title{
SUSTAINABILITY PROGRAMS IN BUSINESS, UNIVERSITIES, AND K-12: EDUCATING STUDENTS AND LEADERS TOWARD A SUSTAINABILITY MINDSET
}

\author{
Danielle J. Camacho, Colorado State University-Global \\ Jill M. Legare, Colorado State University-Global
}

\begin{abstract}
The purpose of this article is to contribute to the growing body of research that focuses on best practices for environmental sustainability education in $K-12$ classrooms. A review of related literature included emerging trends, commitment by business leaders to engage in CSR activities in the community, and opportunities for education at the $K-12$ level. The review of existing literature provides examples as to how sustainability-based environmental programs may provide educational foundations for business leaders and educators. Adopting sustainability course work, programs and projects allows students and educators to acquire knowledge and the competencies necessary for the 21st century. Administrators, business leaders, and educators may find insights into the merits of employing best practices in sustainability education.

Keywords: Environmental Sustainability, Education, K-12, Corporate Social Responsibility, STEM INTRODUCTION

The purpose of this article is to research and report on actions leaders in business and education are taking to address environmental education in their respective organizations. It discusses best practices and opportunities for implementing environmental sustainability education and practices. The literature review includes emerging trends, commitment by business leaders to engage in Corporate Social Responsibility activities in the community, and opportunities for education at the $\mathrm{K}-12$ level.

\section{HISTORICAL PERSPECTIVE OF CSR AND SUSTAINABILITY}

Corporate Social Responsibility (CSR) has become a part of the 21st century business landscape. A heightened awareness of the triple bottom line approach to business has led to increased engagement in community programs and activities (Foo, 2013). The triple bottom line refers to considerations leaders must make regarding the social, environmental, and financial impacts of conducting business (Senge, 2008). Terms such as CSR, "going green," and "sustainable practice" commonly refer to the consideration and use of environmentally responsible practices in business. "Sustainability is a process by which society considers the needs of the current generation without compromising the environmental conditions needed in future generations" (Camacho, 2012). The definition suggests that all members of societyfrom the individual organization to government bodies - must consider their ecological footprint. A shift in mindset occurred during the 1980s when scholars began to support the notion that business leaders have a "duty to society that surpasses the economic objectives of maximizing wealth" (Camacho 2012, p. 2). The 2016 report released
\end{abstract}


by the Governance and Accountability Institute (GAI) showed the growing number of leaders who have implemented sustainability initiatives in the business arena. The report stated that more than $80 \%$ of executives reported sustainability goals and activities in the work place (Governance and Accountability Institute 2016). GAI's report is in contrast to the 2008 study by Bonini, Hintz, and Mendonca where only $60 \%$ of executives acknowledged the need to consider climate change or the corporation's impact on the environment when developing corporate strategy or new products. The increased interest in sustainability practices may be due in part to a renewed sense of obligation and duty to society in business leaders. History demonstrates that education is essential to achieve sustainable change. Educators must pay careful attention to the "interlined environmental, social and economic challenges facing humankind over the next 100 years or so" (Bell, 2016, p. 53). At present, a stop gap exists between the education available to researchers and the specific actions and recommendations for green practice that are available to leaders in education and in business.

\section{TAKING ACTION: CSR IN CORPORATIONS}

In recognition of the continuing global scope of environmental problems, university leaders have begun to incorporate sustainably into university coursework and programs (Widener, Gliedt \& Tziganuk, 2016). In response to the need for environmentally sustainable practices, a number of universities have integrated sustainability into their organizations via a focus on research, teaching, and reporting (Fischer et al., 2015). Fitcher and Tiemann (2018) argued that sustainability actions should be implemented and promoted with entrepreneurial spirit. To gain buy in, green initiatives must be practical, actionable, and promoted by forward-thinking management. Hill and Dyment (2016) described the challenges educators faced in introducing sustainability concepts in the classroom. This 2016 study reported two vital challenges teachers noted as rational for not including detailed sustainability topics in the classroom: the instructors limited understanding of sustainability concepts and the difficulty of embedding sustainability concepts into the curriculum (Hill \& Dyment, 2016). While there is a need to educate our youth, educators themselves may not be prepared to introduce sustainability topics. In 2009, Nolet described how teachers were not prepared to teach cause and effect with respect to the impact of overconsumption and human-caused environmental damage. Preparing educators to address sustainability concepts is paramount to success in launching sustainabilityfocused environmental curriculum.

Ralston (2016)reminded us that "all stakeholders in a school district have the opportunity to contribute to the district's sustainability goals" (p. 7). School administrators and curriculum developers have an opportunity to design sustainability goals for their students. Marcus and Fremeth (2009) argued that schools and corporations must include sustainability in both curriculum and examples of practices. The foundation of formal sustainability curriculum, is resources and expert teachers, which are critical to the success of launching green educational programs in schools and implementing sustainability programs (Rimanoczy \& Pearson, 2010). A formal core curriculum may allow educators to inform students and serve as the catalyst for launching green initiatives. Universities must prepare educators to share and pass this information along to students (Redman, 2013).

\section{Education and Sustainability Programs}

Our leaders have an obligation to educate employees and align sustainability initiatives with the vision and strategy of the organization (O'Dea, 2009; Siegel, 2009). Hill and Dyment (2016) noted the importance of teaching sustainability to help students develop knowledge, values, skills, and a worldview that may lead to sustainable patterns for living. Bell (2016) argued that educators are responsible for preparing students with the skills and values necessary to live sustainable lifestyles. Likewise, university leaders have a duty to consider and incorporate ethics and sustainability in the coursework, lessons, and assignments. A number of universities have developed courses in sustainability up to and including full degree programs (Widener et al., 2016). University leaders have taken steps to respond to the growing concerns of teaching, educating, researching, and reporting sustainability concepts and topics.

Southern New Hampshire University (SNHU) and Arizona State University (ASU) offer degrees in Sustainability and support sustainability-based 
research. In addition to providing courses and degrees in sustainability, both ASU and SHNU require students to complete capstone projects or internships. University leaders work handin-hand with community leaders to describe the opportunities for students to work with agencies and support the growth of sustainability programs. In 2017, for example, ASU Sustainability undergraduate students were placed into internships at the City of Phoenix and at Dell Computers. These touchstone experiences provided a platform for students and leaders to exchange ideas and information on sustainability. Further, the students had an opportunity to apply their education and experiences in the school to solve or address a business problem or plan.

One example of an informal culturalenvironmental awareness is noted in the ways leaders address waste on the ASU campuses. Traditionally, employees and workers were offered trash bins with no options for recycling. In the past decade, recycling has become more prevalent and municipalities now offer options for disposing of and recycling certain goods. The Arizona State University Zero Waste department has a goal to achieve zero solid waste (ASU, n.d.). This university goal and mission serve as the architecture for the design of the waste management plan, which includes the ways in which students and faculty on campus approach waste. On all ASU campuses, disposal bins are clearly labeled as "landfill" and "recycle" and include images to help users determine where to dispose of their waste. The opportunities to learn about sustainability practice can be as simple as changing the labeling on waste bins from "trash" to "landfill." The imagery conjured up by the use of "landfill" is a powerful reminder of the life cycle of our waste and may serve as a deterrent to those who would be more likely to throw away items that are recyclable.

Sterling (2003) informed of the need for holistically sustainable education. Teachers in the 21st century must be flexible and adjust teaching techniques to focus on the learner. Wagner (2011) described several survival skills for our 21st century workforce. Two of the seven essential skills included "critical thinking and problem solving" and "accessing and analyzing information." STEM-based learning programs provide an interdisciplinary approach to education that allow teachers in all subject matters to cross curriculum (Warner \& Elser, 2014). Redman (2013) took these design elements into consideration when developing an interdisciplinary framework to approach the design for a summertime educational program for K-12 teachers. Redman's framework included sustainability competencies such as systems thinking and stakeholder collaboration.

\section{Sustainability and Community Involvement}

Community involvement and partnerships help grow and later sustain green education initiatives. Examples of community partnerships include providing in-service training and continuing education classes or materials for the classroom. Kesavan, Bernacchi, and Mascarenhas (2013) found that, in spite of designing and implementing successful CSR practices, many leaders do not know how to effectively communicate these actions to their stakeholders. Community initiatives such as STEM Fairs by SciTech (azscitech.com) provide a venue for educators and community leaders to share research and best practices with the public (AZScitech, 2018). Leaders in Arizona's power companies, Salt River Project and Arizona Public Service both have clear CSR goals that include community engagement and educational outreach. Salt River Project, for example, offers free education materials and in-classroom grants for teachers (Salt River Project, 2018). Additionally, local museums may provide training and coaching for teachers who are interested in incorporating STEM/Sustainability topics into their coursework. The Arizona Science Center in Phoenix, AZ, for example, offers free camps plus on-site and offsite programs to inform teachers of current trends, topics, and issues in STEM and sustainability (Arizona Science Center, 2018).

There is a need for general communication methods that allow researchers to share educational materials and recommended practices. Sustainability education must reach business leaders and partner with the community to accomplish this goal (Fischer et al., 2015). The Town of Gilbert, AZ, has committed resources to create a partnership with the community and $\mathrm{K}-12$ public schools. The Town of Gilbert's outreach educators designed environmental education programs for $\mathrm{K}-6$ students, such as a "What is your ecological footprint" assignment and a pollution 
index exercise. Educators from the Town of Gilbert bring materials with them to the school to educate both teachers and students to on these sustainability concepts. For example, they created an experiment that incorporates topics that address both water and air pollution. The experiment allows students to understand products or practices that contribute to these environmental problems. The students look at ways to clean the problem up by using teamwork, planning, and ingenuity (Penny Minkalis, Personal Correspondence, 2018). Further, The Town of Gilbert offers sustainable activities such as making seed bombs and focusing on reusing items instead of throwing recyclable items away. The Town of Gilbert programs help students focus on "Thinking before buying, and purchasing wisely" (Penny Minkalis, Personal Correspondence, 2018).

\section{Sustainability in K-12 Education}

Company leaders rely on systems thinking to connect daily activities with the broader scope of work. Systems theory provides a framework from which to understand cycles, causes and effects, and underlying interactions. A systems thinking perspective allows actions to be viewed from multiple viewpoints while accounting for current effects, seeing holistic relationships, and gaining an understanding of how all actions interrelate (Capra, 1996; Senge, 2008). To illustrate the systemsthinking approach, Redman (2013) designed an educational program that focused on engaging students in thinking about the life-cycle of garbage. The activity focused on systems thinking where students collected trash for one week and sorted the items into appropriate bins: landfill, compost, or recycle. The results noted that students gained an understanding of the procedural elements, such as how to sort waste. The students were able to connect daily activities to the bigger picture about waste.

In addition to the growing interest in sustainability at the university level, within the United States, school administrators are building programs and adding sustainability curriculum in $\mathrm{K}-12$ (Mitchell, 2010). One clear avenue to address sustainability lessons is seen with the focus on STEM educational programs. ASU-Preparatory received STEM certification status and serves as a school with many best-practice initiatives in place for students to learn about science, technology, engineering, math, and sustainability. In 2016 the ASU-Prep Polytechnic campus in Mesa, AZ, partnered with ASU to allow fifth- and sixth-grade students to use a community garden at the ASU Polytechnic campus. Collaborative partnerships allow leaders to work together to set precise goals and objectives for green education (Balkau \& Sonnemann, 2010). Students in Grades 5 and 6 were able to participate in the planting, growing, and harvesting of plants. Curriculum in the school that addresses growing plants from seed and measuring, monitoring, and logging the plant growth is an example of this type of site-visit learning.

In 2017, a grant from the Arizona State University Sustainability Initiatives Revolving Fund (SIRF) allowed the administration and lead science teacher to build a grow-box garden on the $\mathrm{K}-8$ campus. This required approval and buy-in from the administrative team and participation from a lead teacher who was willing to manage the garden and create activities for learning.

This project allows the school to carry the message of sustainability to hundreds of young people every year. Students and facilitators will practice gardening skills and the sustainability of the garden will continue with student/faculty/parent/ volunteer support. Students can spend more time learning the art and science of growing, harvesting, and eating healthy food that treads lightly on the earth. From their gardening experience, students learn that you don't need pesticides to grow food, and lettuce with a few holes in it tastes just fine, and that food doesn't come in a box and need to ride in a truck or plane to reach them. Gardening is also a perfect way to demonstrate zero waste. Scraps left over from growing can be composted and all means of production and transportation are re-usable. When completed this project will be a living example of sustainable ingenuity (Ruth Biggs, Personal Correspondence, 2018).

Examples of curriculum elements addressed by having a garden on campus included the ability for students to recognize the positions and functions of the major organs of flowering plants. Hands-on activities allowed students to identify the root, stem, 
and leaf of a plant. As the goals of sustainability have roots and reasoning, a community garden is the perfect foundation for studying ecology. The garden serves as an easily accessed resource that allows students to learn based on their own observations in the field. After the garden was established, the students created a compost bin to help fertilize the plants. In addition to learning about the plant life cycle and where food comes from, these students were also able to learn about composting waste and reusing or repurposing it by transferring the compost back into the soil.

Bestelmeyer et al. (2015) acknowledged that $\mathrm{K}-12$ lesson plans regarding ecology and the environment focused on learning science by reading textbooks instead of engaging with research and the natural environment. Bestlemeyer et al. (2015) found that coupling textbook education with hands-on projects reinforced the practice of interdisciplinary thinking and collaborative skills that helped students become environmentally literate citizens. Hale, Shelton, Richter, and Archambault (2017) found that students gained a more sophisticated understanding of cause and effect, the "socialtechnological-ecological relationships that exist between human-nonhuman and flora-fauna-land interactions," by joining issues of sustainability with geoscience (p. 114). Project-based learning and inquiry-based learning environments also applied in the STEM program at ASU PREP; the goal was to foster creative problem solving when addressing authentic problems (Wilborn, 2017). One example of a sustainability lesson includes a project-based research assignment where students work in groups to determine the pros and cons of energy resources. A specific team-based research assignment may include asking students to work in small groups and investigate green energy and write about how it compares to other forms of nongreen energy (Daniel Nelson, Personal Correspondence, 2018). In addition to writing and research, students can investigate the supply chain of an item to better understand the life-cycle of the materials necessary to get the item from the farm to the table. One learning assignment in the 4th grade STEM classroom at ASU Preparatory asks students to consider the life cycle of the lemon. Students are asked to investigate the entire supply chain to gain a better understanding of the process for growing, transporting, and selling one product.
The investigative process provides students with insight and allows them to question why a product is grown in one region and what the true costs and benefits are for growing a product in one region and shipping it to another (Danielle Houseman, Personal Correspondence, 2018).

In addition to building and growing a sustainable garden, projects that include measurement of invisible forces may also help students to best apply higher-level reasoning in their studies. A two-year study in Colorado partnered $\mathrm{K}-12$ students with the North Fork Valley Monitoring Project by allowing students to build their own air quality monitors (U-Pods) and collect data from those devices (Collier et al., 2015). Students in this program became "citizen scientists" who were able to engage in the discussion of air pollution and the methods to remedy and reduce pollution (Collier et al., 2015).

Traditional pedagogy allows instructors to transmit knowledge to learners. In the 21st century, a shift in pedagogy allowed instructors to move away from transmitting knowledge to inspiring and guiding students. Students in the 21st century are digital natives and are proficient in finding information in the digital world. Students have instant access to information and educators must understand the importance of adjusting from traditional lecture and note taking methods toward action-oriented learning (Camacho \& Legare, 2016). A holistic, systems-based approach to learning may allow for a more effective means of introducing sustainable education and allow students to form their own sustainability mindset. The Vision 2050 report, which lays out a pathway to a "world in which nine billion people can live well, and within the planet's resources, by mid-century," calls for sustainability to be embedded in the curriculum (Bell, 2016, p. 48). Utilizing a holistic approach to learning sustainability will allow students to understand the broader perspective of sustainability and may provide the baseline necessary to navigate and contribute in a more sustainable way.

\section{CLOSING REMARKS}

The purpose of this article was to contribute to the growing body of research that focuses on sustainability and provides practices for incorporating environmental sustainability concepts and programs into $\mathrm{K}-12$ classrooms. A 
review of related literature included emerging trends, commitment by business leaders to engage in CSR activities in the community, and opportunities for education in $\mathrm{K}-12$ level, and it provided examples of how community leaders, business leaders, and educators can create and incorporate sustainability-based environmental programs. Future research investigating the benefits of early education in sustainability may provide insight into the impacts of these educational foundations for business leaders and educators, and how students and educators benefit from adopting sustainability course work, programs, and projects. A focus on sustainability coursework in $\mathrm{K}-12$ provides the necessary educational foundation to help citizens acquire the environmental competencies necessary in the 21st century. In addition, administrators, business leaders, educators, and students may find insights into the merits and applications of applying best practices in sustainability education. 


\section{REFERENCES}

Arizona Science Center. (2018). Educator Events. Retrieved from https://www.azscience.org/educators/educator-events/

Arizona State University. (n.d.). Zero Waste. Retrieved from https://tours.asu.edu/sustainability/zero-waste

AzScitech. (2018). Arizona Science Tech. Retrieved from https:// azscitech.com/

Balkau, F., \& Sonnemann, G. (2010). Managing sustainable performance through the value-chain. Corporate Governance, 10(1), 46-58. doi:10.1108/14720701011021102

Bell, D. V. J. (2016). Twenty-first century education: Transformative education for sustainability and responsible citizenship. Journal of Teacher Education for Sustainability, 18(1), 48-56. http://dx.doi.org.csuglobal.idm.oclc.org/10.1515/ jtes-2016-0004 Retrieved from https://csuglobal.idm.oclc. org/login?url=https://search-proquest-com.csuglobal.idm. oclc.org/docview/1819251483?accountid=38569

Bestelmeyer, S. V., Elser, M. M., Spellman, K. V., Sparrow, E. B., Haan-Amato, S. S., \& Keener, A. (2015). Collaboration, interdisciplinary thinking, and communication: New approaches to K-12 ecology education. Frontiers in Ecology and the Environment 13(1):37-43. doi:10.1890/140130

Camacho, D. (2012). Improving the environmental effects of business practice toward corporate social responsibility. (Doctoral dissertation, Walden University). Available from ProQuest Dissertations Publishing, 2012. 3498379.

Camacho, D., \& Legare, J. (2015). Opportunities to create active learning techniques in the classroom. Journal of Institutional Research, 4. Retrieved from https:// cirt.gcu.edu/jir/documents/2014_v3/volume_4_2015/ jir2015camacholegarepdf

Camacho, D., \& Legare, J. (2016): Shifting gears in the classroom-movement towards personalized learning and competency based education (CBE). The Journal of Competency-Based Education, 1(4), 151-156. doi:10.1002/ cbe2.1032

Capra, F. (1996). The web of life. New York, NY: Anchor BooksDoubleday.

Collier, D., Knight, K., Hafich, M., Hannigan, M., Polmear, D., \& Graves, B. (2015). On the development and implementation of a project-based learning curriculum for air quality in K-12 schools. In 2015 IEEE Frontiers in Education Conference Proceedings (pp. 1-7). doi: 10.1109/FIE.2015.7344246
Fischer, D., Aubrecht, E. L., Brück, M., Ditges, L., Gathen, L., Maximilian, J., Petersmann, M., Rau, J., \& Wellmann, C. (2015). UN Global Action Programme and Education for Sustainable Development: A critical appraisal of the evidence base. Discourse and Communication for Sustainable Education, 6(1), 5-20. doi:10.1515/dcse-20150001

Fichter, K. \& Tiemann, I. (2018). Factors influencing university support for sustainable entrepreneurship: Insights from explorative case studies. Journal of Cleaner Production, 175, 512-524.

Foo, K. Y. (2013). A vision on the role of environmental higher education contributing to the sustainable development in Malaysia. Journal of Cleaner Production, 61, 6-12. doi:10.1016/j.jclepro.2013.05.014

Governance and Accountability Institute. (2016). Flash Report: $82 \%$ of the S\&P 500 Companies Published Corporate Sustainability Reports in 2016. Retrieved from https://3blmedia.com/News/Flash-Report-82-SP500-Companies-Published-Corporate-SustainabilityReports-2016

Hale, A. E., Shelton, C. C., Richter, J., \& Archambault, L. M., (2017). Integrating geoscience and sustainability: Examining socio-techo-ecological relationships within content designed to prepare teachers. Journal of Geoscience Education, 65(2), 101-112. doi:10.5408/16-177.1

Hill, A., \& Dyment, J. E. (2016). Hopes and prospects for the sustainability cross-curriculum priority: Provocations from a state-wide case study. Australian Journal of Environmental Education, 32(3), 225-242. doi:10.1017/aee.2016.20

Kesavan, R., Bernacchi, M. D., \& Mascarenhas, O. J. (2013). Word of Mouse: CSR Communication and the Social Media. International Management Review, 9(1), 58-66.

Marcus, A. A., \& Fremeth, A. R. (2009) Green management matters regardless. Academy of Management Perspectives, 23(3), 17-26.

Mitchell K. Top 10 Eco Education Trends. Alternatives Journal (AJ) - Canada's Environmental Voice [serial online]. October 2010;36(5):6. Available from: Academic Search Premier, Ipswich, MA. Accessed June 23, 2018

Nolet, V. (2009). Preparing sustainably-literate teachers. Teachers College Record, 111(2), 409-442.

O'Dea, K. (2009). It's not just about being green. Packaging Digest, 46(7), 37. Retrieved from http://www.packagingdigest.com 
Ralston, E. (2016). Encouraging employee green behaviour among K-12 custodians to support district sustainability goals. Retrieved from https://viurrspace.ca/handle/10170/876

Redman, E. (2013). Opportunities and challenges for integrating sustainability education into k-12 schools:case study Phoenix, AZ. Journal of Teacher Education for Sustainability,vol. 15, no. 2, pp. 5ñ24, 2013

Rimanoczy, I \& Pearson, T. (2010). Role of HR in the new world of sustainability. Industrial and Commercial Training. 42. 11-17. 10.1108/00197851011013661.

Salt River Project. (2018). Community giving. Retrieved from https://www.srpnet.com/menu/community/contributions.aspx

Senge, P. (2008). The necessary revolution: How individuals and organizations are working together to create a sustainable world. New York, NY: Doubleday.

Siegel, D. (2009). Green management matters only if it yields more green: An economic/strategic perspective. Academy of Management Perspectives, 8, 5-16. Retrieved from http:// journals.aomonline.org/amp/

Sterling, S. (2003). Whole systems thinking as a basis for paradigm change in education: Explorations in the context of sustainability. Unpublished doctoral dissertation, University of Bath, Bath, the United Kingdom.

Wagner, T. (2011). Tony Wagner's seven survival skills. Retrieved from http://www.tonywagner.com/7-survival-skills/

Warner, B. P., \& Elser, M. (2014) How do sustainable schools integrate sustainability education? An assessment of certified sustainable K-12 schools in the United States. Journal of Environmental Education, 46(1), 1-22. doi:10.1080/0095896 4.2014.953020

Widener, J. M., Gliedt, T., \& Tziganuk, A. (2016). Assessing sustainability teaching and learning in geography education. International Journal of Sustainability in Higher Education, 17(5), 698-718. doi:10.1108/IJSHE-03-2015-0050

Wilborn, N. (2017). 5-8 STEM Certification. Retrieved from https:// prezi.com/view/RX7wucptmEAGvA4a82fD 